\title{
. \\ Re-Positioning Libraries: A Consideration Of The Obstacles
}

\author{
Charles B. Lowry
}

I

consider it a "given" that the contribution of academic and research libraries was a central element in the success of the mission of higher education in the twentieth century. That premise leads to a difficult question-does it matter if libraries continue to be central in the century just beginning? Here I will make a second assumption-that it really does matter a great deal. At the risk of sounding pessimistic, it helps to understand the obstacles to re-positioning libraries successfully so that they may continue their vital contribution of providing access to scholarly information. These are largely beyond our immediate ability to remedy. That does not mean we should not try to understand them and to find the allies who can help us do the work of shaping the future of libraries - and there are many such allies. During the last two years, I have written closely allied pieces that have appeared in these pages exploring several topics that in my view are critical to the question of the future of libraries-on change, on the so-called "paradigm shift" and on intellectual property. In large measure, this essay is a capstone for all of them. ${ }^{1}$

Among the most immediate and obvious of our problems is one that libraries have been grappling with since I began my career 30 years ago in the great higher education downturn of the early 1970s-a declining share of fiscal resources. That downturn brought an end to what has been called the "golden age of library collecting." Libraries have never recovered. A recent cover story in the Chronicle of Higher Education devoted itself to "The Crumbling Intellectual Foundation" and described budget cuts for libraries, university presses, journals, and culture, which are converging to threaten the infrastructure on which professors and students depend. The key point was that in budget downturns, some items traditionally have been protected. These include the largest single line item in higher education, faculty salaries. At the same time, tuition, the major source of support, has been protected from dramatic increases-at least until re- 
cently. States have also protected capital spending in order to create economic stimulus for recovery. They have been able to do this because construction is funded by longterm bonded indebtedness and does not have a large or immediate tax implication for which lawmakers pay a political price. However, the "budget items that support intellectual life are much smaller and much more vulnerable, so many academics believe they will not be able to bounce back when the economy recovers." 2

The compelling evidence that this has happened before and is cyclical can be found in a Mellon study published ten years ago. We learned from the study University Libraries and Scholarly Communication ... that the library share of the educational and general expenditures had been declining for about thirty years. ${ }^{3}$ Now, we can say forty years. In short, with each economic cycle of retrenchment and recovery, academic libraries have not rebounded, but in fact have lost ground. It is happening again today in the current economic downturn, in which states are hunting for ways to live within their means while not revisiting recent massive tax cuts at the end of the last boom/bubble cycle. This imperiled infrastructure of scholarly communication is interconnected with other issues. Declining budgets mean fewer book purchases from scholarly presses and that, in turn, leads to a further downward spiral in the fortunes of these presses. Serials cuts combined with aggressive if not usurious pricing practices of commercial STM publishers lead to cancellation and further price increases. Space does not allow me to say more about the fact that the vigorous emergence of networked electronic information places further pressures on these fragile budgets. Suffice it to say, great harm is being done by these economic realities. As an institution, academic libraries (that is to say library managers) are poorly positioned to do anything about it.

Information technology is the friend of libraries! Information technology is the enemy of libraries! I feel equally comfortable with both of these statements because taken together they contain the seeds of the future and a partial solution to our vexing budget dilemmas - the future is emphatically a different kind of library. ${ }^{4}$ If information technology presents positive developments for libraries, it also is the source of several significant problems. I enumerate them at the risk of belaboring the obvious.

It is a commonly held view that the evolution of copyright in the intellectual property regime since 1976 has been in response to change in technology and has gradually strengthened the position of copyright holders and weakened that of the reading public. The underlying cause is the "commercialization" of information. The process can be easily seen in the terms of DMCA, WIPO, UCITA and the very policies of the Library of Congress. The promoters have predicated their case on the importance of the need for economic protection of information in the digital environment. None have had a genuine concern about protecting readers or for that matter the "the progress of science and useful arts" to use the constitutional phrase. It is the gradual erosion of user rights (represented by legitimate scholarly use, fair use, classroom use, etc.) — not technology per se-that will be the greatest challenge to building the virtual "personalized information environment" that draws from digital libraries. But help may be on the way with recently submitted legislation: Congresswoman Zoe Lofgren has sponsored H.R. 5522, "the Digital Choice and Freedom Act of 2002," and Congressmen Rick Boucher and John Doolittle H.R. 5544, "the Digital Media Consumers' Rights Act." ${ }^{5}$ 
Nonetheless, the academy must face its own complicity in the problem and try to do something to correct it. As a major producer of new knowledge, faculty (and as a result universities) are bound into the system which may actually begin to inhibit the advance of research and invention. So in great measure the problem lies with the current scholarly information regime, in which research universities and the Federal Government use tax resources to discover new knowledge that is given freely to publishers, who discover nothing, but then sell it back to libraries at a premium. This problem can be overcome by reshaping the scholarly information exchange and restoring the constitutional balance to copyright law. ${ }^{6}$

The world of distributed computing and the Internet was not invented by or for libraries. Those who did invent it are often deeply committed to libraries, with notable exceptions. For years we have heard from some IT prognosticators that libraries are a thing of the past and will wither and go away as the Internet makes all information easily accessible if not freely available. They do not understand that libraries are about serving "information," not print-content, and computing is about technology, not information. Libraries use computing to enhance access to information content. Nonetheless, these opposing voices often have had the high ground and have influenced administrative and budget decision makers. Increasingly, people realize that this vision of the future is in many ways flawed, but much harm has already been done.

In addition, there is a closely related development in the academy-that is, the competition for budgetary resources presented by computing centers. People used to say that "academic libraries" were the black hole of university and college budgets. Today, presidents and provosts may find this idea quaint and reflect that it is their computing operations that best bear this appellation. Nonetheless, the experience for three decades has been one of static or declining library budgets and growing computing budgets. I will not belabor the point that this competition is largely speaking one that libraries have lost.

Although libraries are changing and adapting pretty rapidly to the emerging world of networked information, there is a subtle and ironic dimension. Two recent issues of the Chronicle of Higher Education capture it best. In the July 12, 2002 issue, the Information Technology column-“Do Libraries Really Need Books?" investigated controversial projects at some colleges that move the printed word out of sight. In the November 16, 2001 issue, another Information Technology column—“The Deserted Library" observed that students work online and reading rooms empty out-leading some campuses to add Starbucks. ${ }^{7}$ We hear constantly about declining gate counts, circulation, and reference transactions. Many of us wring our hands at this lack of library use, and a superficial analysis might lead decision makers to assume that, indeed, libraries are a thing of the past and are withering. The reality is that they are not-they are changing, and in my university as in others, students and faculty are more than ever dependent on libraries, but in significantly different ways. They are dependent on our virtual services as much as our physical collections. We have not yet found the way to measure effectively this activity or its impact. Again, help may be on the way with efforts to develop "new measures," such as the Association of Research Libraries (ARL) and International Coalition of Library Consortia (ICOLC) sponsored work on "E-Measures." 
The last challenge I would mention is that much of what underpins excellence in the academy cannot be easily evaluated on a cost-benefit basis. Judging from my own experience, one will not find many serious scholars in any academic institution who would argue that libraries are a frill that makes no difference in their work in the classroom or in research, but they might not be able to quantify it. At the same time, decision makers-particularly politicians who vote our funding-are asking for "output measures" that assess impact. Again, help may be on the way in the form of the ARL LibQUAL $+{ }^{\mathrm{TM}}$ project that is aimed at assessment of service quality in libraries from the perspective of the user. It can help a library identify problem areas deserving of deeper investigation and process improvement.

So what is to be done? Unfortunately, there is no silver bullet, and I am not sanguine about finding easy solutions. But there are a few general strategies that may help. With respect to budgets in particular, directors and deans of libraries do not sit close to the levers of power. Where academic deans have a significant advantage because of the "automatic" protection of their greatest asset-faculty salaries-libraries do not. Nevertheless, provosts, deans, and faculty can be persuaded to the cause of protecting libraries as a matter of self-interest. That persuasion will be part of a systematic effort that must involve all librarians who have regular contact with faculty, not just library managers. Nothing will work but a campus-wide consensus that libraries are a "cost of doing business" just as much as paying the annual increase in the electric bill.

Similarly, the use of information technology is providing new opportunities and challenges in research, instruction, and organization. For academic libraries, this raises the question of our role in knowledge management or content management (to use current terminology). The answer will be found through widespread experimentation as this new information environment evolves. Even though we cannot quite see what a "library" will look like, I believe the contours are becoming clearer. ${ }^{8}$

The control of intellectual property, in my view, is the key issue in controlling the future. Again, it is not a matter over which libraries can exercise much direct influence, although we must be in the thick of the debate. Part of the solution lies squarely with the federal government and its policies. In a nutshell, the results of research supported by the U.S. taxpayer should be in the public domain, with the exception of information with national security implications narrowly defined. Moreover, copyright law must be modified to restore the constitutional balance between property and readership, and also to assure the original principal of the Founding Fathers as enshrined in the Article 1 Section 8 of the U.S. Constitution. ${ }^{9}$ A truly conservative president, congress, and courts should support such changes that "conserve" constitutional principle and historic precedent. Moreover, the academy must finally free itself of the "Faustian bargain" it has made with commercial publishers and support vigorously noncommercial scholarly publishing. This can be done best by assuring the healthy continuation of university and association presses, but also effective support of initiatives like SPARC, the Public Library of Science, and institutional repositories. The burden of this work falls most heavily on the leadership of organizations like the American Association of Universities and the Research I institutions. The burden of making this understood falls to the library community and every member of the profession who believes in the basic principles of the "Freedom to Read." 10 
Charles B. Lowry, Ph. D. is Dean of Libraries and Professor of Information Studies at the University of Maryland; he may be contacted via e-mail at: clowry@deans.umd.edu.

\section{Notes}

1. Charles B. Lowry, "The More Things Change ..." portal: Libraries and the Academy 1, 4 (October 2001): vii-ix; "When's this Paradigm Shift Ending?" portal: Libraries and the Academy 2, 3 (July 2002): vii-xii; "Fair Use and Digital Publishing: An Academic Librarian's Perspective," portal: Libraries and the Academy 1, 2 (April 2001): 191-196.

2. Scott Smallwood, "The Crumbling Intellectual Foundation," The Chronicle of Higher Education (September 30, 2002): A10.

3. Anthony M. Cummings et al., University Libraries and Scholarly Communication: A Study Prepared for The Andrew W. Mellon Foundation (Washington, DC: Association of Research Libraries, 1992).

4. Lowry, "When's this Paradigm Shift Ending?"

5. Zoe Lofgren, "H.R. 5522: Digital Choice and Freedom Act of 2002." Available: <http:// thomas.loc.gov/cgi-bin/query/z?c107:H.R.5522:> [January 29, 2003]; Rick Boucher and John Doolittle, “H.R. 5544, Digital Media Consumers' Rights Act of 2002." Available: <http:/ / thomas.loc.gov/cgi-bin/query/z?c107:H.R.5544:> [January 29, 2003].

6. Lowry, "Fair Use and Digital Publishing: An Academic Librarian's Perspective."

7. Scott Carlson, "Do Libraries Really Need Books?" The Chronicle of Higher Education 48, 44 (July 12, 2002): A31. Available: <http://chronicle.com/free/v48/i44/44a03101.htm> [January 29, 2003]; Scott Carlson, "The Deserted Library," The Chronicle of Higher Education 48, 12 (November 16, 2001): A35. Available: <http://chronicle.com/free/v48/i12/ 12a03501.htm > [January 29, 2003].

8. Lowry, "When's this Paradigm Shift Ending?" x-xii.

9. Lowry, "Fair Use and Digital Publishing," 191.

10. American Library Association, "Freedom to Read Statement." Available: <http:// www.ala.org/alaorg/oif/freeread.html> [January 29, 2003]. 